\title{
Keefektifan Virtual Class dengan Google Classroom dalam Pembelajaran Fisika Dimasa Pandemi Covid-19
}

\author{
Andira Permata ${ }^{1 *}$, Yoga Budi Bhakti ${ }^{2}$ \\ 1.2Program Studi Pendidikan Fisika Universitas Indraprasta PGRI Jakarta \\ JI. Raya Tengah No. 80, Kel. Gedong, Kec. Pasar Rebo, Jakarta Timur 13760 \\ "E-mail: andirapermataAP@gmail.com
}

\begin{abstract}
Abstrak
Pada saat ini, sekolah sedang melaksanakan pembelajaran daring dari rumah karena adanya pandemi Covid19, namun guru dan siswa tetap melakukan pembelajaran berbasis online atau Virtual Class melalui berbagai aplikasi salah satunya yaitu Google Classroom. Penerapan Google Classroom masih sangat awam bagi peserta didik karena biasanya guru mengajar secara langsung dengan bertatap muka.Tujuan dari artikel ini adalah untuk mengetahui keefektifan penerapan Virtual Class dengan Google Classroom dalam pembelajaran fisika dimasa pandemi Covid-19. Metode yang digunakan berupa pengisian angket melalui Google Form pada Siswa SMPkelasVII-IX secara acak mewakili satu Provinsi yaitu Jawa Barat. Dari hasil survei deskriptif diperoleh hasil bahwa Google Classroom kurang efektif dalam pembelajaran fisika, akan tetapi sudah efektif dalam pembelajaran virtual class dan dapat digunakan sebagai aplikasi pembelajaran dimasa pandemi Covid-19. Sehingga dapat disimpulkan bahwa siswa masih membutuhkan guru secara langsung dalam proses pembelajaran fisika.
\end{abstract}

Kata kunci: Virtual Class, Google Classroom, danPembelajaranFisika.

\begin{abstract}
At this time, the school is conducting online learning from home due to the Covid-19 pandemic, but teachers and students still do online-based or Virtual Class learning through various applications, one of which is Google Classroom. The implementation of Google Classroom is still very public for learners, because usually teachers teach face-to-face. The purpose of this article is to determine the effectiveness of the Virtual Class implementation with Google Classroom in the Covid-19 pandemic Physics study. The method used in the form of charging poll through the Google Form in junior high school class VII-IX randomly represents one province namely West Java. From the results of a descriptive survey the results of the Google Classroom are less effective in physical learning, but are effective in virtual class learning and can be used as a Covid-19 pandemic learning app. So it can be concluded that students still need teachers directly in the process of learning physics.
\end{abstract}

Keywords: Virtual Class, Google Classroom, and Physics Learning

\section{PENDAHULUAN}

Covid-19 adalah penyakit yang disebabkan oleh infeksi virus SARS-CoV-2, pertama kali diidentifikasi di kota Wuhan, di provinsi Hubei Cina pada Desember 2019. Covid-19 telah menyebar ke berbagai negara di dunia, termasuk Indonesia. Jumlah kasus positif virus corona (Covid-19) di Indonesia terus bertambah. Covid-19 sebelumnya dikenal sebagai Novel 201 Novel Coronavirus
(2019-nCoV) penyakit pernapasan (Yuzar, 2020), sebelum Organisasi Kesehatan Dunia (WHO) menyatakan nama resmi sebagai Covid-19 pada bulan Februari 2020. Ghebreyesus menyebut, $\mathrm{C}-\mathrm{o}=$ corona, $\mathrm{v}-\mathrm{i}=$ virus, dan $D=$ disease. Jadi Covid bisa diartikan penyakit virus corona, angka 19 menandai tahun pertama kali virus teridentifikasi. Badan Kesehatan Dunia (WHO) mengungkapkan cara penyebaran virus corona dari satu orang ke lainnya. Menurut 
WHO, ketika seseorang yang menderita COVID-19 batuk atau bernapas, mereka melepaskan seperti tetesan cairan yang juga terdapat virus corona. Kebanyakan tetesan atau cairan itu jatuh pada permukaan dan benda di dekatnya seperti meja, kursi dan benda-benda lainnya. Orang bisa terpapar atau terinfeksi COVID-19 dengan menyentuh permukaan atau benda yang terkontaminasi dan kemudian menyentuh mata, hidung, atau mulut.

Sejumlah Pemerintah Daerah mengambil kebijakan meliburkan sekolah dan menunda pelaksanaan ujian nasional (UN) sebagai langkah antisipasi penyebaran virus corona atau Covid-19. Menurut Mendikbud (2020), dampak penyebaran Covid-19 akan berbeda dari satu wilayah ke wilayah lainnya. Kami siap dukung kebijakan yang diambil Pemda. Keamanan dan keselamatan peserta didik serta guru dan tenaga kependidikan itu yang utama. Menurut gubernur Jawa Barat Ridwan Kamil (2020) mengatakan bahwa konsepnya bukan libur, tapi bersekolah di rumah dalam dua minggu ke depan para siswa nantinya akan belajar di rumah dan bertanya dengan arahan para gurunya secara jarak jauh memggunakan sistem daring atau menggunakan $\mathrm{hp}$.

Kelas Maya (Virtual Class) adalah lingkungan belajar yang diadakan tanpa tatap muka secara langsung antara pengajar dengan siswa. Di mana pengajar menyediakan bahan ajar dalam konten digital yang bisa diakses, disimpan, dan dibagikan melalui internet yang bisa diakses kapan saja dan dimana saja sehingga siswa masih dapat melakukan pembelajaran (Kroker, 1994). Mengenai Virtual Class, Potter (1997) mengatakan : dalam sistem pembelajaran melalui internet isi pembelajaran disampaikan secara online. Dalam sistem pembelajaran ini siswa berdiskusi, belajar, bertanya dan mengerjakan soal-soal latihan secara online. Semua proses pembelajaran dapat dilakukan tanpa menuntut siswa hadir di ruang kelas tertentu, tetapi mereka berinteraksi satu sama lain untuk mendiskusikan pelajaran seperti yang terjadi di kelas biasa. System pembelajaran ini sering kali disebut e-learning, virtual learning, virtual Classroom, atau virtual campus.

Google Classroom atau ruang kelas Google merupakan suatu serambi pembelajaran campuran untuk ruang lingkup pendidikan yang dapat memudahkan pengajar dalam membuat, membagikan dan menggolongkan setiap penugasan tanpa kertas (Mayasari, dkk, 2019). Software tersebut telah diperkenalkan sebagai keistimewaan dari Google Apps for Education yang rilis pada tanggal 12 Agustus 2014. Menurut website resmi dari Google, aplikasi Google Classroom merupakan alat produktivitas gratis meliputi email, dokumen dan penyimpanan. Classroom didesain untuk memudahkan guru (pengajar) dalam menghemat waktu, mengelola kelas dan meningkatkan komunikasi dengan siswasiswanya. Dengan Google Classroom ini dapat memudahkan peserta didik dan pengajar untuk saling terhubung di dalam dan diluar sekolah (Wicaksono, 2020). Google Classroom dapat diakses melalui 2 cara yaitu melalui website dan aplikasi. Untuk website dapat diakses menggunakan browser apapun seperti Chrome, FireFox, Internet Explorer ataupun Safari. Sedangkan untuk aplikasi dapat diunduh secara gratis melalui Playstore untuk Android dan App Store untuk iOS.

Fisika adalah pelajaran tentang gejala alam yang dipecahkan menggunakan rumusrumus untuk membuktikan suatu kejadian alam tersebut. Sehingga dalam pembelajaran fisika guru akan menjelaskan rumus-rumus, memberikan contoh-contoh penerapannya dalam kehidupan sehari-hari, dan melakukan praktikum di laboratorium. Selanjutnya dikemukakan pula bahwa "fisika merupakan sebagai ilmu pengetahuan yang berusaha menguraikan serta menjelaskan hukum alam dan kejadian-kejadian dalam alam dengan gambaran menurut pemikiran manusia" (Druxes, 1986:12). Adanya pendapat demikian menunjukkan bahwa fisika menjelaskan tentang hukum alam. Sehingga dapat dikemukakan bahwa "Pembelajaran Fisika adalah bagian dari pelajaran ilmu alam. IImu alam secara klasikal dibagi menjadi dua bagian, yaitu (1) ilmu-ilmu fisik (physical 
sciences) yang objeknya zat, energi, dan transformasi zat dan energi, (2) ilmu-ilmu biologi (biological sciences) yang objeknya adalah makhluk hidup dan lingkungannya" (Kemble, 1966:7). Maka dari itu pembelajaran fisika akan meningkatkan kemampuan berpikir siswa untuk mengembangkan nalarnya dalam melakukan eksperimen.

\section{METODE/EKSPERIMEN}

Metode penelitian yang digunakan dalam penelitian ini adalah metode angket yaitu dengan cara membagikan kuesioner dalam bentuk Google Form. Jumlah responden yang telah mengisi angket sebanyak 63 siswa-siswi SMP, mulai dari kelas 7 sampai kelas 9.Menurut Sugiyono (2016:192) "Angket merupakan teknik pengumpulan data di mana partisipan atau responden mengisi pertanyaan atau pernyataan kemudian setelah diisi dengan lengkap mengembalikan kepada peneliti". Penelitian ini hanya menguji efektivitas penggunaan Google Classroom dalam pembelajaran fisika, oleh karena itu kuesioner dibagikan secara acak pada siswa SMP yang telah menggunakan aplikasi Google Classroom selama masa pembelajaran dari rumah.

Kemudian data yang diperoleh akan dianalisis dan dihitung rata-ratanya menggunakan Skala Likert untuk mengetahui seberapa efektif penggunaan Google Classroom dalam pembelajaran fisika dimasa pandemic Covid-19. Menurut Sugiyono (2017:134) skala likert digunakan untuk mengukur sikap, pendapat, dan persepsi seseorang atau sekelompok orang tentang fenomena sosial untuk setiap pertanyaan atau pernyataan responden harus mendukung sebuah pertanyaan untuk dipilih.

Data dari penelitian ini berupa pendapat siswa tentang kemudahan Google Classroom dalam pembelajaran fisika, penerimaan siswa terhadap kemudahan Google Classroom sebagai virtual class (kelas maya) dan harapan tentang penggunaan Google Classroom.
Tabel 1. Instrument SkalaLikert

\begin{tabular}{cc}
\hline Penilaian & Skor \\
\hline Sangat setuju (SS) & 5 \\
Setuju (S) & 4 \\
Kurang Setuju(KS) & 3 \\
Tidak Setuju (TS) & 2 \\
Sangat Tidak Setuju & 1 \\
(STS) & \\
\hline Sumber :Sugiyono (2016:132) &
\end{tabular}

\section{HASIL DAN PEMBAHASAN}

\section{HASIL}

Kuesioner dibagi menjadi tiga variabel yang masing-masing variabelnya terdapat 5 pernyataan yaitu variabel pendapat siswa tentang kemudahan Google Classroom dalam pembelajaran fisika dimasa pandemi Covid-19, penerimaan siswa terhadap kemudahan Google Classroom sebagai virtual class (kelas maya) dan harapan tentang penggunaan Google Classroom.

Dengan menggunakan skala likert jika bentuk pernyataan positif maka diberi skor 5 , 4, 3, 2, 1. Bentuk jawaban dari sangat setuju, setuju, ragu-ragu atau kurang setuju, tidak setuju, dan sangat tidak setuju dengan skor berurutan dari 5 sampai 1 .

Jenis Kelamin 63 Responden

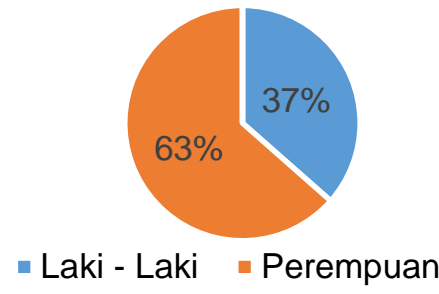

Gambar 1. Rata-rata responden dilihat dari jenis kelamin 
Tabel 2.Hasil Pernyataan Variabel Pertama

\begin{tabular}{|c|c|c|c|c|c|}
\hline $\begin{array}{c}\text { Kemudahan } \\
\text { Google } \\
\text { Classroom } \\
\text { dalam } \\
\text { pembelajaran } \\
\text { fisika }\end{array}$ & STS & TS & RG & $\mathbf{S}$ & SS \\
\hline $\begin{array}{ll}1 & \text { Menggunak } \\
\text { - } & \text { an Google } \\
& \text { Classroom } \\
\text { memungkin } & \text { kan saya } \\
\text { dalam } & \\
\text { menyelesai } \\
\text { kan tugas- } \\
\text { tugas lebih } \\
\text { cepat }\end{array}$ & $\begin{array}{l}0 \\
(0 \%)\end{array}$ & $\begin{array}{l}1 \\
(1,6 \\
\%)\end{array}$ & $\begin{array}{l}10 \\
(15, \\
9 \%)\end{array}$ & $\begin{array}{l}32 \\
(50,8 \\
\%)\end{array}$ & $\begin{array}{l}20 \\
(31,7 \\
\%)\end{array}$ \\
\hline $\begin{array}{ll}2 & \text { Google } \\
\cdot & \text { Classroom } \\
& \text { meningkatk } \\
& \text { an } \\
& \text { kemampua } \\
& \text { n belajar } \\
& \text { fisika saya }\end{array}$ & $\begin{array}{l}3 \\
(4,8 \\
\%)\end{array}$ & $\begin{array}{l}14 \\
(22, \\
2 \%)\end{array}$ & $\begin{array}{l}23 \\
(36, \\
5 \%)\end{array}$ & $\begin{array}{l}18 \\
(28,6 \\
\%)\end{array}$ & $\begin{array}{l}5 \\
(7,9 \\
\%)\end{array}$ \\
\hline $\begin{array}{ll}3 & \text { Menggunak } \\
\text { - } & \text { an Google } \\
& \text { Classroom } \\
& \text { efisien } \\
& \text { dalam } \\
\text { pembelajar } & \text { an fisika } \\
\end{array}$ & $\begin{array}{l}5 \\
(7,9 \\
\%)\end{array}$ & $\begin{array}{l}13 \\
(20, \\
6 \%)\end{array}$ & $\begin{array}{l}20 \\
(31, \\
7 \%)\end{array}$ & $\begin{array}{l}19 \\
(30,2 \\
\%)\end{array}$ & $\begin{array}{l}6 \\
(9,5 \\
\%)\end{array}$ \\
\hline $\begin{array}{ll}4 & \text { Google } \\
\cdot & \text { Classroom } \\
& \text { meningkatk } \\
& \text { an } \\
& \text { produktivita } \\
& \text { s saya } \\
& \text { dalam } \\
& \text { pembelajar } \\
& \text { an }\end{array}$ & $\begin{array}{l}0 \\
(0 \%)\end{array}$ & $\begin{array}{l}7 \\
(11, \\
1 \%)\end{array}$ & $\begin{array}{l}12 \\
(19 \\
\%)\end{array}$ & $\begin{array}{l}33 \\
(52,4 \\
\%)\end{array}$ & $\begin{array}{l}11 \\
(17,5 \\
\%)\end{array}$ \\
\hline $\begin{array}{ll}5 & \text { Google } \\
\cdot & \text { Classroom } \\
& \text { sangat } \\
& \text { berguna } \\
& \text { dalam } \\
& \text { proses } \\
& \text { pembelajar } \\
& \text { an fisika } \\
& \text { saya }\end{array}$ & $\begin{array}{l}2 \\
(3,2 \\
\%)\end{array}$ & $\begin{array}{l}13 \\
(20, \\
6 \%)\end{array}$ & $\begin{array}{l}20 \\
(31, \\
7 \%)\end{array}$ & $\begin{array}{l}22 \\
(34,9 \\
\%)\end{array}$ & $\begin{array}{l}6 \\
(9,5 \\
\%)\end{array}$ \\
\hline
\end{tabular}

Tabel 3.Hasil Pernyataan Variabel Kedua

\begin{tabular}{|c|c|c|c|c|c|}
\hline $\begin{array}{c}\text { Penerimaan } \\
\text { siswa } \\
\text { terhadap } \\
\text { kemudahan } \\
\text { Google } \\
\text { Classroom } \\
\text { sebagai } \\
\text { virtual class } \\
\text { (kelasmaya) }\end{array}$ & STS & TS & RG & $S$ & SS \\
\hline $\begin{array}{l}\text { 1. Pengguna } \\
\text { an }\end{array}$ & $\begin{array}{l}0 \\
(0 \%)\end{array}$ & $\begin{array}{l}4 \\
(6,3\end{array}$ & $\begin{array}{l}6 \\
(9,5\end{array}$ & $\begin{array}{l}31 \\
(49,\end{array}$ & $\begin{array}{l}22 \\
(34,9\end{array}$ \\
\hline
\end{tabular}

\begin{tabular}{|c|c|c|c|c|c|c|}
\hline \multicolumn{2}{|c|}{$\begin{array}{c}\text { Penerimaan } \\
\text { siswa } \\
\text { terhadap } \\
\text { kemudahan } \\
\text { Google } \\
\text { Classroom } \\
\text { sebagai } \\
\text { virtual class } \\
\text { (kelasmaya) }\end{array}$} & \multirow[t]{2}{*}{ STS } & TS & $\mathbf{R G}$ & $\mathbf{S}$ & SS \\
\hline & $\begin{array}{l}\text { Google } \\
\text { Classroo } \\
m \text { mudah } \\
\text { dipelajari }\end{array}$ & & \%) & \%) & $2 \%)$ & \%) \\
\hline 2. & $\begin{array}{l}\text { Tampilan } \\
\text { Google } \\
\text { Classroo } \\
\text { msangatj } \\
\text { elas dan } \\
\text { mudah } \\
\text { dipahami }\end{array}$ & $\begin{array}{l}0 \\
(0 \%)\end{array}$ & $\begin{array}{l}2 \\
(3,2 \\
\%)\end{array}$ & $\begin{array}{l}8 \\
(12, \\
7 \%)\end{array}$ & $\begin{array}{l}28 \\
(44, \\
4 \%)\end{array}$ & $\begin{array}{l}25 \\
(39,7 \\
\%)\end{array}$ \\
\hline 3. & $\begin{array}{l}\text { Mudah } \\
\text { bagi saya } \\
\text { menggun } \\
\text { akan } \\
\text { Google } \\
\text { Classroo } \\
m \text { sesuai } \\
\text { dengan } \\
\text { yang } \\
\text { diinginkan }\end{array}$ & $\begin{array}{l}1 \\
)^{(1,6 \%}\end{array}$ & $\begin{array}{l}2 \\
(3,2 \\
\%)\end{array}$ & $\begin{array}{l}5 \\
(7,9 \\
\%)\end{array}$ & $\begin{array}{l}38 \\
(60, \\
3 \%)\end{array}$ & $\begin{array}{l}17 \\
(27 \\
\%)\end{array}$ \\
\hline 4. & $\begin{array}{l}\text { Dengan } \\
\text { memudah } \\
\text { kan } \\
\text { memperol } \\
\text { eh } \\
\text { pengumu } \\
\text { man, } \\
\text { materi } \\
\text { dan } \\
\text { pengump } \\
\text { ulan } \\
\text { tugas } \\
\text { menjadi } \\
\text { lebih } \\
\text { efisien }\end{array}$ & $\begin{array}{l}0 \\
(0 \%)\end{array}$ & $\begin{array}{l}2 \\
(3,2 \\
\%)\end{array}$ & $\begin{array}{l}7 \\
(11, \\
1 \%)\end{array}$ & $\begin{array}{l}33 \\
(52, \\
4 \%)\end{array}$ & $\begin{array}{l}21 \\
(33,3 \\
\%)\end{array}$ \\
\hline 5. & $\begin{array}{l}\text { Sangat } \\
\text { mudah } \\
\text { bagi saya } \\
\text { untuk } \\
\text { menggun } \\
\text { akan } \\
\text { Google } \\
\text { Classroo } \\
m \\
\end{array}$ & $\begin{array}{l}0 \\
(0 \%)\end{array}$ & $\begin{array}{l}0 \\
(0 \% \\
)^{2}\end{array}$ & $\begin{array}{l}4 \\
(6,3 \\
\%)\end{array}$ & $\begin{array}{l}35 \\
(55 \\
6 \%)\end{array}$ & $\begin{array}{l}24 \\
(38,1 \\
\%)\end{array}$ \\
\hline
\end{tabular}

Tabel 4.Hasil Pernyataan Variabel Ketiga

\begin{tabular}{|c|c|c|c|c|c|}
\hline $\begin{array}{c}\text { Harapan } \\
\text { tentang } \\
\text { penggunaan } \\
\text { Google } \\
\text { Classroom }\end{array}$ & STS & TS & $\mathbf{R G}$ & $\mathbf{S}$ & SS \\
\hline $\begin{array}{ll}\text { 1. } & \text { Aplikasi } \\
\text { Google } \\
\text { Classroo }\end{array}$ & $\begin{array}{l}3 \\
(4,8 \% \\
)^{2}\end{array}$ & $\begin{array}{l}7 \\
(11,1 \\
\%)\end{array}$ & $\begin{array}{l}23 \\
(36,5 \\
\%)\end{array}$ & $\begin{array}{l}25 \\
(39, \\
7 \%)\end{array}$ & $\begin{array}{l}5 \\
(7,9 \\
\%)\end{array}$ \\
\hline
\end{tabular}




\begin{tabular}{|c|c|c|c|c|c|}
\hline $\begin{array}{c}\text { Harapan } \\
\text { tentang } \\
\text { penggunaan } \\
\text { Google } \\
\text { Classroom }\end{array}$ & STS & TS & $\mathbf{R G}$ & $\mathbf{s}$ & SS \\
\hline $\begin{array}{l}m \text { sangat } \\
\text { berguna } \\
\text { untuk } \\
\text { digunaka } \\
\text { n dalam } \\
\text { pembelaj } \\
\text { aran } \\
\text { fisika }\end{array}$ & & & & & \\
\hline $\begin{array}{l}\text { 2. Tampilan } \\
\text { Google } \\
\text { Classroo } \\
\text { m sangat } \\
\text { jelas dan } \\
\text { mudah } \\
\text { dipahami }\end{array}$ & $\begin{array}{l}1 \\
(1,6 \%\end{array}$ & $\begin{array}{l}1 \\
(1,6 \\
\%)\end{array}$ & $\begin{array}{l}7 \\
(11,1 \\
\%)\end{array}$ & $\begin{array}{l}33 \\
(52 \\
4 \%)\end{array}$ & $\begin{array}{l}21 \\
(33,3 \\
\%)\end{array}$ \\
\hline $\begin{array}{l}\text { 3. Google } \\
\text { Classroo } \\
\text { m mudah } \\
\text { digunaka } \\
\mathrm{n}\end{array}$ & $\begin{array}{l}0 \\
(0 \%)\end{array}$ & $\begin{array}{l}0 \\
(0 \%)\end{array}$ & $\begin{array}{l}5 \\
\text { (7,9 } \\
\%)\end{array}$ & $\begin{array}{l}33 \\
(52, \\
4 \%)\end{array}$ & $\begin{array}{l}25 \\
(39,7 \\
\%)\end{array}$ \\
\hline $\begin{array}{l}\text { 4. Penggun } \\
\text { aan } \\
\text { Google } \\
\text { Classroo } \\
\text { m mudah } \\
\text { dipelajari }\end{array}$ & $\begin{array}{l}0 \\
(0 \%)\end{array}$ & $\begin{array}{l}1 \\
(1,6 \\
\%)\end{array}$ & $\begin{array}{l}7 \\
(11,1 \\
\%)\end{array}$ & $\begin{array}{l}36 \\
(57 \\
1 \%)\end{array}$ & $\begin{array}{l}19 \\
(30,2 \\
\%)\end{array}$ \\
\hline $\begin{array}{l}\text { 5. Google } \\
\text { Classroo } \\
m \text { mudah } \\
\text { diakses }\end{array}$ & $\begin{array}{l}0 \\
(0 \%)\end{array}$ & $\begin{array}{l}0 \\
(0 \%)\end{array}$ & $\begin{array}{l}4 \\
(6,3 \\
\%)\end{array}$ & $\begin{array}{l}29 \\
(46 \\
\%)\end{array}$ & $\begin{array}{l}30 \\
(47,6 \\
\%)\end{array}$ \\
\hline Keterangan : & \multicolumn{5}{|c|}{$\begin{array}{l}\text { STS = SangatTidakSetuju } \\
\text { TS = TidakSetuju } \\
\text { RG = Ragu-Ragu } \\
\text { S = Setuju } \\
\text { SS = SangatSetuju }\end{array}$} \\
\hline
\end{tabular}

\section{PEMBAHASAN}

Tabel 5.Hasil Rata-Rata Kuesioner Variabel Pertama

Kemudahan Google Classroom dalam pembelajaran fisika

\begin{tabular}{clc}
\hline No. & \multicolumn{1}{c}{ Pernyataan } & Rata-Rata \\
\hline 1. & $\begin{array}{l}\text { Menggunakan Google } \\
\text { Classroom } \\
\text { memungkinkan } \\
\text { dalam menyelesaikan } \\
\text { tugas-tugas lebih cepat }\end{array}$ \\
\hline 2. & $\begin{array}{l}\text { Google Classroom } \\
\text { meningkatkan } \\
\text { kemampuan belajar fisika } \\
\text { saya }\end{array}$ \\
\hline 3. & \\
\hline & $\begin{array}{l}\text { MenggunakanGoogle } \\
\text { Classroom efisien dalam } \\
\text { pembelajaran fisika }\end{array}$ \\
\hline
\end{tabular}

Kemudahan Google Classroom dalam pembelajaran fisika

\begin{tabular}{clc}
\hline No. & \multicolumn{1}{c}{ Pernyataan } & Rata-Rata \\
\hline 4. & $\begin{array}{l}\text { Google Classroom } \\
\text { meningkatkan } \\
\text { produktivitas saya dalam } \\
\text { pembelajaran }\end{array}$ \\
\hline 5. & $\begin{array}{l}\text { Google Classroom sangat } \\
\text { berguna dalam proses } \\
\text { pembelajaran fisika saya }\end{array}$ \\
\hline & 3,269 \\
\hline & Jumlah & $\mathbf{3 , 4 8 2}$ \\
\hline Dari hasil survei deskriptif untuk
\end{tabular}
variabel pendapat siswa terhadap kemudahan Google Classroom dalam pembelajaran fisika, hasilnya diperoleh rata-rata 3,482 . Artinya dari 5 pernyataan yang ada di kuesioner dapat dikatakan bahwa rata-rata siswa masih RaguRagu dengan masing-masing pernyataan yang ada dalam kuesioner terkait dengan kemudahan Google Classroom dalam pembelajaran fisika.

Sehingga dapat dikatakan bahwa Google Classroomkurang efektif dalam pembelajaran fisika dimasa pandemic Covid19, karena siswa masih membutuhkan guru secara langsung dalam proses pembelajaran fisika.

Tabel 6. Hasil Rata-Rata Kuesioner Variabel

$$
\text { Kedua }
$$

\section{Penerimaan siswa terhadap kemudahan} Google Classroom sebagai virtual class (kelasmaya)

\begin{tabular}{lll}
\hline No. & \multicolumn{1}{c}{ Pernyataan } & $\begin{array}{l}\text { Rata- } \\
\text { Rata }\end{array}$ \\
\hline 1. & $\begin{array}{l}\text { Penggunaan Google } \\
\text { Classroom mudah dipelajari }\end{array}$ \\
\hline 2. & $\begin{array}{l}\text { Tampilan Google Classroom } \\
\text { sangat jelas dan mudah } \\
\text { dipahami }\end{array}$ \\
\hline 3. & $\begin{array}{l}\text { Mudah bagi saya } 4,079 \\
\text { menggunakan } \\
\text { Classroom sesuai dengan } \\
\text { yang diinginkan }\end{array}$ \\
\hline 4. & $\begin{array}{l}\text { Dengan Google Classroom } \\
\text { memudahkan memperoleh } \\
\text { pengumuman, materi dan } \\
\text { pengumpulan tugas menjadi } \\
\text { lebih efisien }\end{array}$ \\
\hline $\begin{array}{l}\text { Sangat mudah bagi saya } \\
\text { untuk menggunakan Google }\end{array}$ \\
\hline
\end{tabular}




\begin{tabular}{l}
\hline Classroom \\
\hline Dumlah \\
\hline Dari hasil survei deskriptif untuk \\
variabel Penerimaan siswa terhadap \\
kemudahan Google Classroom sebagai virtual \\
class (kelas maya), hasilnya diperoleh rata- \\
rata 4,177. Artinya dari 5 pernyataan yang ada \\
di kuesioner dapat dikatakan bahwa rata-rata \\
siswa Setuju dengan masing-masing \\
pernyataan yang ada dalam kuesioner terkait \\
dengan Penerimaan siswa terhadap \\
kemudahan Google Classroom sebagai virtual \\
class (kelas maya). \\
Sehingga dapat dikatakan bahwa \\
Google Classroom sudah efektif dalam \\
pembelajaran virtual class (kelas maya), \\
karena siswa dapat menerima Google \\
Classroom dengan mudah dari segi \\
penggunaan, tampilan dan memperoleh akses \\
pengumuman, materi, serta tugas yang lebih \\
efisien.
\end{tabular}

Tabel 7.Hasil Rata-Rata Kuesioner Variabel Ketiga

\begin{tabular}{lcc}
\multicolumn{4}{c}{ Ketiga } \\
\hline \multicolumn{4}{c}{ Harapan Siswa tentang penggunaan } \\
Google Classroom
\end{tabular}

Sehingga dapat dikatakan bahwa
Google Classroom sudah efektif dalam aplikasi pembelajaran . Karena sesuai dengan harapan siswa, yaitu tampilan Google Classroom yang mudah dipahami, mudah digunakan, mudah dipelajari dan mudah diakses.Menurut Iftakhar (2016) menyatakan kelebihan dari Google Classroom antara lain yaitu:

a. Mudah digunakan: Sangat mudah digunakan. Desain Google Kelas sengaja menyederhanakan antarmuka instruksional dan opsi yang digunakan untuk tugas pengiriman dan pelacakan; komunikasi dengan keseluruhan kursus atau individu juga disederhanakan melalui pemberitahuan pengumuman dan email.

b. Menghemat waktu: Ruang kelas Google dirancang untuk menghemat waktu. Ini mengintegrasikan dan mengotomatisasi penggunaan aplikasi Google lainnya, termasuk dokumen, slide, dan spreadsheet, proses pemberian distribusi dokumen, penilaian, penilaian formatif, dan umpan balik disederhanakan dan disederhanakan.

c. Berbasis cloud: Google Classroom menghadirkan teknologi yang lebih profesional dan otentik untuk digunakan dalam lingkungan belajar karena aplikasi Google mewakili sebagian besar alat komunikasi perusahaan berbasis claud yang digunakan di seluruh angkatan kerja profesional.

d. Fleksibel: Aplikasi ini mudah diakses dan dapat digunakan oleh instruktur dan peserta didik di lingkungan belajar tatap muka dan lingkungan online sepenuhnya. $\mathrm{Hal}$ ini memungkinkan para pendidik untuk mengeksplorasi dan memengaruhi metode pembelajaran yang dibalik lebih mudah serta mengotomatisasi dan mengatur distribusi dan pengumpulan tugas dan komunikasi dalam beberapa milieus instruksional.

e. Gratis: Google Kelas sendiri sudah dapat digunakan oleh siapapun untuk membuka kelas di Google kelas asalkan memiliki akun gmail dan bersifat gratis. Selain itu dapat mengakses semua aplikasi lainnya, seperti Drive, Documents, Spreadsheets, Slides, dll. Cukup dengan mendaftar ke akun Google.

f. Ramah seluler: Google Classroom dirancang agar responsif. Mudah digunakan pada perangkat mobile 


\section{UCAPAN TERIMAKASIH}

manapun. Akses mobile ke materi pembelajaran yang menarik dan mudah untuk berinteraksi sangat penting dalam lingkungan belajar terhubung web saat ini.

\section{PENUTUP}

\section{SIMPULAN}

Pada kondisi saat ini di mana siswa sedang diwajibkan untuk belajar dari rumah karena adanya wabah Covid-19, penggunaan Google Classroom belum efektif dalam pembelajaran fisika karena siswa masih membutuhkan guru secara langsung dalam proses pembelajaran fisika.

Sedangkan siswa dapat menerima Google Classroom sebagai aplikasi virtual class (kelas maya) karena Google Classroom mudah dipelajari, digunakan dan diakses. Google Classroom hanya efektif digunakan sebagai virtual class untuk beberapa mata pelajaran saja, namun tidak untuk pelajaran fisika.

Bila konsep Google Classroom menyediakan video pembelajaran dan video praktikum, maka akan lebih efektif dalam pembelajaran fisika dimasa pandemi Covid-19.

\section{SARAN}

Dimasa pandemi ini sebaiknya siswa tetap belajar dari rumah menggunakan sumber belajar yang telah diarahkan oleh guru masing-masing.

Google Classroom adalah salah satu aplikasi yang dapat digunakan dalam proses pembelajaran secara virtual class (kelas maya). Walaupun belum efektif digunakan dalam pembelajaran fisika, siswa tetap dapat memanfaatkan Google Classroom dengan baik untuk mata pelajaran lainnya.
Terima kasih kepada teman-teman Pendidikan Fisika 2017, dan kepada siswasiswi Responden yang telah membantu menyelesaikan penelitian ini.

\section{REFERENSI}

Druxes \& Herbar. (1986). Kompedium Didaktik Fisika (terjemahan). Bandung: CV. Remaja Karja.

Iftakhar, S. (2016). Google classroom: what works and how. Journal of Education and Social Sciences, 3(1), 12-18.

Kemble, E.C. (1966). Physical science, its structure and development. Messachusetts : The M.I.T. Press.

Kroker, A., \& Weinstein, M. A. (1994). Data trash: The theory of the virtual class. New World Perspectives.

Mayasari, F., Dwita, D., Jupendri, J., Jayus, J., Nazhifah, N., Hanafi, K., \& Putra, N. M. (2019). Pelatihan Komunikasi Efektif Media Pembelajaran Google Classroom Bagi Guru Man 2 Model Pekanbaru. Jurnal Pengabdian UntukMu NegeRI, 3(1), 18-23.

Potter \& Perry. (1997). Fudamental of Nursing Concept: Buku Ajar Fundamental Keperawatan. Volume 1. Edisi 4. United States of America: Mosby.

Sugiyono. (2016). Metode Penelitian Kuantitatif, Kualitatif dan R\&D. Bandung: PT Alfabet.

Sugiyono. (2017). Metode Penelitian Kuantitatif, Kualitatif, dan R\&D. Bandung : Alfabeta, CV.

Wicaksono, M. D. (2020). Pemanfaatan Google Classroom dalam Strategi Pembelajaran Kooperatif pada Mata Pelajaran Ips Kelas Viii. Inspirasi (Jurnal IImu-IImu Sosial), 17(1).

Yuzar, D. N. (2020). Penyakit Menular Dan Wabah Penyakit Covid-19. https://doi.org/10.31219/osf.io/5bqvw 